\title{
POPULARITAS SELEBRITI SEBAGAI ALAT KOSMETIKA POLITIK
}

\author{
Dyah Tantri Efrina Putri \\ Muradi \\ Pascasarjana Ilmu Politik \\ Fakultas Ilmu Sosial dan Ilmu Politik Universitas Padjajaran \\ email: d_tantri83@yahoo.com \\ email:muradi@unpad.ac.id
}

\begin{abstract}
ABSTRAK
Fenomena selebriti untuk turut naik ke panggung perpolitikan semakin semarak. Terlihat dari sebagian besar partai yang meminang para selebriti untuk masuk menjadi kandidat sebagai wakil rakyat. Fenomena ini tidak terlepas dari adanya perubahan sistem pemerintahan dan politik sejak zaman kemerdekaan hingga saat ini. Perubahan sistem inilah yang otomatis turut mempengaruhi sistem kepartaian. Euforia demokrasi masa reformasi menjadikan pemilih dapat memilih langsung wakil rakyat. Dahulu dimana selebriti hanya merupakan "boneka pajangan etalase politik", saat ini dapat lebih berperan sebagai aktor politik. Tidak dapat dipungkiri, popularitas selebriti merupakan modal politik yang dimanfaatkan partai politik untuk mendulang perolehan suara.
\end{abstract}

Kata kunci : popularitas, selebriti, politik, pendulang suara.

\begin{abstract}
Celebrity phenomenon had spreding into political area recently. The phenomenon was showed from the candidate choosen from the parties to become their representatives. Most political parties recently choosen celebrity to become their candidate as people representatives. This phenomenon was related to the changes of political system since Indonesia independence until recently. The transformation automatically influenced political parties system. Democracy euphoria during reformation era brought change for the voter as their able to choose their representatives direcly. As a comparison, celebrityies were able to become politician recently, rather than to become political mannequins. Thereby, celebrity popularity had become political asset for the parties raising their voters.
\end{abstract}

Keywords : popularity, celebrity, politics, raising voters

\section{PENDAHULUAN}

Gemerlap dan hingar bingar selebritis turut mewarnai kancah perpolitikan di Indonesia. Selebritis dari kalangan artis baik film dan sinetron, musisi, pembawa acara, model dan mantan ratu kecantikan berlomba-lomba turut mencalonkan diri baik itu Pilkada, Pilgub maupun pemilihan legislative. Sejumlah partai kerapkali tetap menyisipkan 
beberapa nama-nama artis tersebut dalam daftar calon dari partainya. Sudah sejak zaman Orde Baru, para artis menjadi anggota MPR dan DPR, sebut saja nama Yoseano Waas yang merupakan aktor pendukung perfileman Indonesia dan aktif dalam PARFI (Persatuan Artis Film Indonesia) sekaligus mantan anggota MPR, selain itu ada pula Rhoma Irama yang menjadi salah satu mascot terpenting Partai Persatuan Pembangunan (PPP) dan aktor kawakan Sophan Sophiaan.

Dibawah kekuasaan Orde Baru, pemerintahan menggunakan sistem unikameral atau yang dikenal dengan sistem satu kamar (Fatwa, 2009, p. 316). MPR memiliki kewenangan sebagai lembaga tertinggi Negara, keanggotannya terdiri dari anggota DPR, Utusan Daerah dan Utusan Golongan. Dalam konteks ini, selebritis - artis menjadi salah satu utusan golongan dari kalangan seniman dan budayawan. Tidak berbeda halnya dengan utusan golongan lainnya seperti akademisi, politisi, tentara ataupun pengusaha. Utusan golongan tersebut hanya sebagai "kedok" akomodasi yang dibuat oleh rezim Soeharto. Proses legislasi yang diajukan pemerintah "mulak" akan mendapat persetujuan oleh DPR. Tidak perlu handal menjadi legistlator, karena pada dasarnya pengesahan dan pemberlakuan suatu Undang-undang bukan ditentukan oleh mereka. Dalam konteks Orde Baru maka tidak menjadi soal apakah artis-artis yang menjadi wakil rakyat akan membawa suara rakyat, atau setidaknya kepentingan para artis. Keberadaan mereka tidak lebih sebagai pajangan etalase "seolaholah demokrasi” yang dipertontonkan Orde Baru.

Tumbangnya rezim Soeharto pada tahun 1998 memberikan banyak perubahan dalam segala hal, terutama dalam sistem pemerintahan dan politik di Indonesia. Amandemen UUD 1945 menjadi salah satu produk masa reformasi. Perubahan sistem parlemen dari unikameral menjadi bikameral turut mewarnai euphoria demokrasi. Bikameral atau meminjam istilah Moh.Yamin sebagai "sistem majelis perundang-undangan kembar" merupakan praktik pemerintahan yang menggunakan dua kamar. Penggunakan sistem bikameral biasanya didorong oleh pertimbangan bahwa satu kamar dapat mengimbangi dan membatasi kekuasaan dari kamar lainnya. Dikuatirkan bila menggunakan satu kamar memberi peluang untuk menyalahgunakan kekuasaan karena mudah dipengaruhi oleh situasi politik (Budiardjo, 1977, p. 180).

\section{POPULARITAS, SELEBRITI DAN POLITIK}

Perubahan sistem inilah yang menjadi salah satu pemicu semakin maraknya selebriti masuk ke dalam kancah perpolitikkan. Awal 
keberadaan mereka yang dianggap hanya sebagai "boneka pajangan etalase politik" kini dapat menjadi aktor-aktor politik yang memerankan politik lebih jauh. Sistem kepartaian dengan menggunakan First Past The Post (FPTP) dan Proportional Open List System, dimana rakyat diberikan kebebasan memilih secara langsung wakil rakyatnya. Oleh karena bermodalkan kandidat, maka mereka harus menunjukkan kemampuan dan kualitas sebagai legislator yang layak. Para selebriti memiliki kekuasaan untuk ikut menyetujui atau membuat sebuah undangundang, harus mampu berargumentasi, berpendapat, berdebat, melakukan lobby, memiliki pemahaman dan pengetahuan yang sangat baik dalam bidang komisinya serta dapat memproduksi sebuah undang-undang.

Popularitas merupakan nilai tambah modal komunikasi politik para selebriti. Mereka lebih sering tampil di acara televisi diberbagai acara dan membintangi sinetron tertentu, bahkan mereka pun ada yang memiliki fans atau penggemar berat. Sehingga hal ini memudahkan mereka untuk bisa lebih dikenal oleh masyarakat. Bahkan bagi masyarakat bawah, awam serta tidak memiliki wawasan tentang politik, apatis terhadap politik dan tidak mengetahui atau tidak mengenal calon-calon yang mereka pilih, apakah cagubnya, calegnya maka dapat dengan mudahnya mereka memilih calon dari kalangan selebritis.

Fenomena selebritis terjun dalam panggung perpolitikkan pada dasarnya tidak dapat dipersalahkan. Karena para selebritis juga merupakan warga Negara Indonesia yang memiliki persamaan hak memilih dan dipilih. Seperti yang dapat kita lihat dalam UUD 1945 pada pasal 28 lebih berisikan tentang HAM, hak untuk mencalonkan, mengajukan diri maka sah-sah saja. Selama mereka siap mengemban suatu amanah dan tanggung jawab publik dan memenuhi persyaratan menjadi pemimpin, maka diperbolehkan. Pro Kontra terhadap pencalonan selebriti pun terjadi dimasyarakat. Masyarakat yang sudah antipati terhadap "jargon ideology" partai dan bergeser memilih selebriti menjadi alternatif partisipasi politiknya, namun disisi lain masyarakat merasa bahwa kader partai yang potensial masih lebih layak untuk terjun ke ranah politik. Para kader tersebut lebih baik dalam segi pendidikan, pengalaman politik dan organisasi. Hal ini sangat disayangkan mengingat para artis itu dicalonkan karena kepopularanya semata. Dampaknya adalah adanya keraguan dan kekhawatiran masyarakat terhadap masa depan bangsa jika yang memimpin adalah para artis.

Hal ini bukan merupakan hal aneh yang hanya terjadi di Indonesia. Pada pertengahan Oktober 2003 di 
Amerika Serikat artis Arnold Schwarnegger, kandidat Republikan terpilih menjadi Gubernur California. Hal ini memperlihatkan kekuataan popularitas selebriti yang mampu menggalang dan dipergunakan untuk menjaring pemilih, bagi partai politik. Selebriti merupakan salah satu modal politik partai. Diyakini, kalangan selebritis mampu memberikan sumbangan suara bagi partai politik. Tidak heran bila antara para selebritis dan partai politik memiliki hubungan yang saling menguntungkan. John Cork, warga asal Los Angeles sempat menulis sepucuk surat dalam surat kabar Time (Time, 10 November 2003),

"Pesona pribadi akan selalu lebih bermakna ketimbang politik, memiliki nama tenar lebih penting ketimbang mampu menjawab pertanyaan-pertanyaan seputar isuisu kampanye, jika Anda seorang bintang maka media akan melakukan apapun untuk meliput kampanye anda,"

Menurut Cork, terpilihnya Arnold pada saat itu menggarisbawahi satu hal yaitu terjadinya kultus selebriti. Pemujaan selebriti menjadi suatu kepercayaan baru, melahirkan agama baru. Inilah yang pada akhirnya membangun "kerajaan baru" (Guardini, 1996). Dalam kerajaan ini para selebritilah yang menjadi raja dan ratunya. Bintang dan khalayak berhubungan secara khas. Khalayak memandang sang selebriti sebagai gemerlap nun jauh di langit, yang tak dapat tersentuh namun sekaligus menyilaukan. Mimpi dan cita-cita khalayak adalah mendekati bintang atau menjadi bintang.

Dalam konteks seperti ini, peran selebriti pun penggantikan kehebatan para pahlawan. Mengutip sejarawan dan pemenang hadiah Pulitzer, Daniel J. Boorstin (Boorstin, 1992, p. 57)

seseorang yang dikenal karena keterkenalannya.

$\begin{array}{rrr} & \text { pahlawan dikenali } \\ \text { karena prestasi atau }\end{array}$
pencapaiannya, sementara

selebriti karena citra

atau merek dagangnya.Pahlawan membentuk

dirinya,selebriti

dibentuk oleh media.Pahlawan adalah orang besar, selebriti adalah

sebuah nama besar."

Maka, tak semua selebriti adalah pahlawan dan sebaliknya tak semua pahlawan dapat menjadi selebriti. Pahlawan terkadang luput dari dari sorot kamera dan liputan. Sedangkan selebritis hidup bak seorang bintang. Selebriti merupakan magnet media, pusat sorotan kamera, bergelimang ketenaran. Popularitas selebriti adalah produk media. selebritis tentunya sudah dikenal masyarakat melalui sinetron, gosip, atau tayangan yang lainnya, sehingga apa yang terjadi pada dirinya 
memiliki nilai berita. Masyarakat merasa dekat dengan artis karena terpaan media setiap harinya. Maka tak heran ketika artis mencalonkan atau dicalonkan dalam pemilihan umum, hal ini segera menjadi perhatian masyarakat. Seperti yang dikutip dalam diktum terkenal ilmuwan politik bahwa "pers mungkin tidak selalu berhasil dalam mendorong orang untuk memikirkan sesuatu, tetapi sangat berhasil sekali dalam mendorong....(orang) untuk menentukan apa yan g perlu mereka pikirkan (Cohen, 1963)."

Selebriti merupakan bagian dari konsumerisme visual yang dijajakan oleh media dan televisi. Pengkultusan yang dilakukan terus menerus oleh pihak media menjadikan, selebritis menjadi kian popular. Popularitas dimaknai sebagai dikenal dan disukai oleh banyak orang atau tindakan seseorang dalam aktualisasi diri untuk dapat dikenal oleh masyarakat luas. Dalam dunia pers dikenal istilah "man makes news" artinya setiap tokoh memiliki berita, atau berita dapat diangkat dari mereka yang memiliki nilai berita (populer). Karena kepopulerannya, apapun yang terjadi pada diri si tokoh tersebut dapat menjadi perhatian khalayak, baik dari sisi karya seninya, gaya hidup ataupun segala sesuatu yang berhubungan dengan dirinya. Popularitas merupakan potensi yang inheren dengan profesi keartisannya. Seringkali orang yang memiliki kualitas, namun tidak berada dalam lingkaran kekuasaan dan popularitas menjadi tersisih. Semakin banyak jumlah penggemar, maka semakin tinggi pula nilai jual selebritis yang bersangkutan.

Banyak partai politik yang
mendadak "meminang" para selebritis untuk menjadikan mereka mesin pendongkrak suara. Keberhasilan beberapa selebritis sebut saja Deddy Mizwar, Zumi Zola, Rano Karno, Anang Hermansyah, Dessy Ratnasari, Dede Yusuf, Rieke Diah Pitaloka turut memenangi pertarungan suara di parlemen. Berdasarkan Surat Keputusan (SK) KPU Nomor 416/Kpts/KPU/2014 tentang penetapan perolehan kursi partai politik dan calon anggota DPR dan DPD terpilih, setidaknya ada 18 orang yang berprofesi sebagai artis berhasil lolos ke Senayan. Keberhasilan ini dapat menginspirasi selebriti lain untuk turut mengadu peruntungannya. Hal ini semakin mengukuhkan telah datangnya suatu era baru dalam demokrasi di Indonesia yaitu, "Celebrity Politics".

Seperti penjelasan diatas, perubahan sistem politik yang berimbas pada perubahan sistem kepartaian di Indonesia, secara tidak langsung mempengaruhi perilaku pemilih dalam berpartisipasi. Pemilih yang berawal memberikan pilihan dengan sudut pandang tatanan ideologis menjadi pemilih rasional yang mengutamakan figur. Hal ini 
diperkuat dengan beberapa penelitian, salah satunya yang dilakukan oleh Lembaga Survei Indonesia pada tahun 2011 (LSI, 2001) yang menemukan bahwa instabilitas pilihan pada partai kemungkinan terkait dengan kecenderungan pemilih rasional. Pemilih telah menetapkan standard tujuan atau prioritas keberhasilan pemimpin berupa: pertumbuhan ekonomi, kemakmuran, persatuan nasional, pendidikan, dan penegakan hukum. Masyarakat lebih percaya pada individu-individu ketimbang partai politik, dengan standar individu berupa integritas pribadi, kepedulian sosial, dan kompetensi profesional. Ada kecenderungan meningkatnya peran iklan politik dalam menonjolkan figur, sehingga hanya figur yang memiliki kekuatan iklan di media massa, atau memiliki kesempatan di media massa saja (artis selebriti) yang menjadi perhatian. Iklan politik menjadikan budaya populaer dalam politik semakin menguat, masyarakat tidak merasa bahwa politik dan kekuasaan merupakan hal yang menakutkan, namun menjadi tempat berlangsungnya tata kelola hidup bersama menjamin kompetisi yang fair dan adil untuk mendapatkan kekuasaanya (Sufyanto, 2015).

BUDAYA POPULAR PENGUAT KEMENANGAN SELEBRITI
Popular Culture atau sering disebut budaya pop mulai mendapat tempat dalam kehidupan masyarakat di Indonesia. Budaya pop sebagai "lokasi pertarungan", banyak yang terjadi dalam makna ini (pertarungan kekuasaan atas makna yang terbentuk dan beredar di masyarakat) ditentukan dan diperdebatkan. Bahkan terkesan, budaya pop hanya pelayan dari sistem kapitalisme dan patriarkhi, membiarkan kesadaran palsu membius masyarakat. Budaya pop juga dapat dilihat sebagai lokasi dimana makna-mana tersebut dipertandingkan dan ideologi dominan bisa saja diusik. Antara pasar dan berbagai ideologi, antara pemodal dan produser, antara sutradara dan aktor, antara penerbit dan penulis, antara kapitalis dan kaum pekerja, antara perempuan dan laki-laki, antara heteroseksual dan homoseksual, kelompok kulit hitam dan putih, tua dan muda, antara apa makna segala sesuatunya dan bagaimana artinya merupakan pertarungan atas kontrol (terhadap makna) yang berlangsung terus menerus" (Strinati, 2003).

Budaya pop adalah budaya pertarungan makna dimana segala macam makna bertarung memperebutkan hati masyarakat. Dan sekarang ini, model praktis dan pemikiran pragmatis mulai berkembang dalam pertempuran makna itu. Budaya pop sering diistilahkan dengan budaya McDonald atau budaya MTV. 
Kepraktisan, pragmatisme, dan keinstanan dalam pola kehidupan menjadi salah satu ciri khasnya. Disini, media, baik cetak atau elektronik, menjadi salah satu ujung tombak public relation untuk menerjemahkan budaya pop ala MTV langsung ke jantung peradaban masyarakat itu. Televisi menjadi media yang efisien dalam mengkomoditaskan segala sesuatu dan menjualnya. Televisi menjadikan manusia sebagai komoditas yang dapat "diperjualbelikan" dengan alasan: ada yang membutuhkannya. Dalam pengertian ini, seorang idola turut ikut dijual oleh media dalam konsep budaya pop ini. Idola harus menjual dirinya, televisi (dan media lain) menjadi semacam "toko serba ada" yang memajang idola itu agar dapat dibeli oleh masyarakat. Dan masyarakat bisa melihat, memegang, bahkan mencicipi apa yang dijual oleh idola dan medianya itu. Semua itu mempunyai model kepentingannya masing-masing, alias saling membutuhkan. Salah satu unsur memerlukan unsur yang lain.

Dalam hal politik, dengan masuknya budaya popular, masyarakat seolah-olah tidak merasa lagi bahwa kekuasaan dan politik merupakan hal yang menakutkan yang dahulu hanya diisi oleh para elit-elit politik sebagai kelas social terbatas seperti kalangan penguasa, pejabat dan kelompok ningrat. Sehingga banyak kalangan tersohor yang pada awalnya tidak memiliki tradisi politik pun menjadi tertarik untuk bergabung di dalamnya, seperti artis (selebrity) yang berlomba untuk turut terlibat dalam pertas perpolitikkan. Keterlibatannya tidak sekedar menjadi figuran objek untuk menarik simpati pemilih namun lebih dari itu sebagai bagian yang terjun langsung dalam suksesi kekuasaan untuk menjadi subjek kandidat anggota legislatif maupun eksekutif.

Dalam kompetisi politik wajib mempopulerkan dirinya kepada publik pemilih secara meluas. Sebab popularitas menjadi factor penting dalam kompetisi suksesi kekuasaan di seluruh tingkatan. Dalam studi voting behavior untuk melihat seseorang dapat terpilih atau tidak dalam kompetisi politik secara lansung harus memenuhi harapan masyarakat melalui tiga tahapan, antara lain: popularitas, kapasitas (kepantasan) dan elektabilitas. Popularitas artinya sejauh mana public mengenal seseorang yang terlibat dalam kontes suksesi kekuasaan politik. Popularitas mendorong pemahaman pemilih untuk melihat kandidat pantas menjadi perwakilan publik. Jika nilai kepantasan kandidat memadai, maka pasti akan menaikkan nilai elektabilasnya, sehingga tak heran bila seseorang yang memiliki tingkat kepopulerannya tinggi, memiliki peluang menggalang suara dari para pemilih dengan tingkat yang tinggi pula. Elektabilitas seseorang yang 
popular seperti para selebriti menjadi tinggi.

Merupakan lompatan besar dalam politik Indonesia sebagai wujud konsolidasi demokrasi, yaitu kecenderungan baru partai untuk mencalonkan orang yang popular (Mietzner, 2009) . Periode sebelumnya orang lebih memfokuskan pada pengaruh politik atau kapasitas finansial seseorang, namun hari ini popularitas telah menggeser hal tersebut. Popularitas individual adalah senjata paling ampuh yang ditemukan partai politik selama puluhan tahun berjibaku dalam pemilu. Pergeseran orientasi itulah yang ditangkap oleh sebagian besar partai politik untuk melakukan pinangan "dadakan" untuk meningkatkan elektabilitas di masyarakat. Seperti terlihat dalam Pemilu 2014, terdapat 79 artis dari 6.550 caleg yang masuk daftar calon sementara (DCS) untuk bersaing merebut kursi di Senayan. Ke-9 parpol tersebut, Partai Amanat Nasional (PAN) penyumbang artis terbanyak, yaitu 18 orang. Kemudian Partai Gerindra 15 orang, Partai Kebangkitan Bangsa (PKB) 14 orang, PDI Perjuangan 7 orang, Partai Demokrat 7 orang, Partai Nasionalis Demokrat (NasDem) 6 orang, Partai persatuan Pembangunan (PPP) 6 orang, Partai Golkar 4 orang dan Partai Hanura 2 orang. Dari 79 artis tersebut, sebanyak 35 merupakan caleg perempuan dan 44 adalah laki-laki.
Lalu, dari jumlah tersebut, 24 di antaranya berada di nomor urut puncak, san selebihnya di nomor urut sepatu.

Meruaknya kandidat artis, menguatkan bahwa budaya populer telah merasuki ruang publik, mencairkan ideology masyarakat akan arti kekuasaan dan politik, artis selebriti yang memiliki modal ketenaran dan kepopuleran dapat menjadi bagian dalam suksesi kekuasaan sekaligus memiliki tingkat elektabilitas yang tinggi atas modal politiknya tersebut. Masyarakat yang terbius atas suguhan instan budaya populer pun tidak segan turut memilih idolanya untuk memberikan kepercayaan untuk memilih mereka sebagai wakil politiknya.

PERILAKU

PEMILIH TERHADAP FENOMENA POPULARITAS SELEBRITI

Terlepas dari pro dan kontra selebriti berbondong-bondong ke panggung perpolitikkan, maka yang harus dilihat bagaimana dampak perilaku pemilih. Pemilih diartikan sebagai semua pihak yang menjadi tujuan utama para konsestan untuk mereka pengaruhi dan yakinkan agar mendukung dan kemudian memberikan suaranya kepada konsestan yang bersangkutan (Firmanzah, 2007). Pemilih dalam hal ini dapat berupa konsituen maupun masyarakat pada umumnya. Konstiuen adalah kelompok masyarakat yang merasa diwakili 
oleh suatu ideologi tertentu yang kemudian termanifestasikan dalam institusi politik seperti partai politik dan seorang pemimpin. Adapun perilaku pemilih menurut Surbakti adalah : "Akivitas pemberian suara oleh individu yang bekaitan erat dengan kegiatan pengambilan keputusan untuk memilih atau tidak memilih (to vote or not to vote) didalam suatu pemilihan umum (Pilkada secara langsung-pen. Bila voters memutuskan untuk memilih (to vote) maka voters akan memilih atau mendukung kandidat tertentu (Surbakti, 1997)

Keputusan

untuk

memberikan dukungan dan suara tidak akan terjadi apabila tidak terdapat loyalitas pemilih yang cukup tinggi kepada calon pemimpin jagoannya. Begitu pula sebaliknya, pemilih pemilih tidak akan memberikan suaranya kalau mereka menganggap bahwa sebuah partai atau calon pemimpin tidak loyal serta tidak konsisten dengan janji dan harapan yang telah mereka berikan.

Perilaku pemilih juga sarat dengan ideologi antara pemilih dengan partai politik atau kontestan pemilu. Masing-masing kontestan membawa ideologi yang saling berinteraksi. Selama periode kampanye pemilu, muncul kristalisasi dan pengelompokkan antara ideology yang dibawa kontestan. Masyarakat akan mengelompokkan dirinya kepada kontestan yang memiliki ideologi sama dibawa dengan yang mereka anut sekaligus juga menjauhkan diri dari ideologi yang berseberangan dengan mereka. Perilaku pemilih dapat dianalisis dengan tiga pendekatan yaitu (Asfar, 2006):

1) Pendekatan Sosiologis

Pendekatan sosioligis sebenarnya berasal dari Eropa, kemudian di Amerika dan pendidikan Eropa. Karena itu, flananngan menyebutnya sebagai model sosiologi politik Eropa. David Denver, ketika menggunakan pendekatan ini untuk menjelaskan perilaku memilih masyarakat Inggris, menyebut model ini sebagai social determinism approach. Pendekatan ini pada dasarnya menjelaskan bahwa karakteristik sosial dan pengelompokan-

pengelompokan sosial mempunyai pengaruh yang cukup signifikan dalam menentukan perilaku pemilih seseorang. Karakteristik sosial (seperti pekerjaan, pendidikan dsb) dan karekteristik atau latar belakang sosiologis (seperti agama, wilayah, jenis kelamin,umur dsb) merupakan faktor penting dalam menentukan pilihan politik.

Pendek kata, pengelompokan sosial seperti umur (tua- 


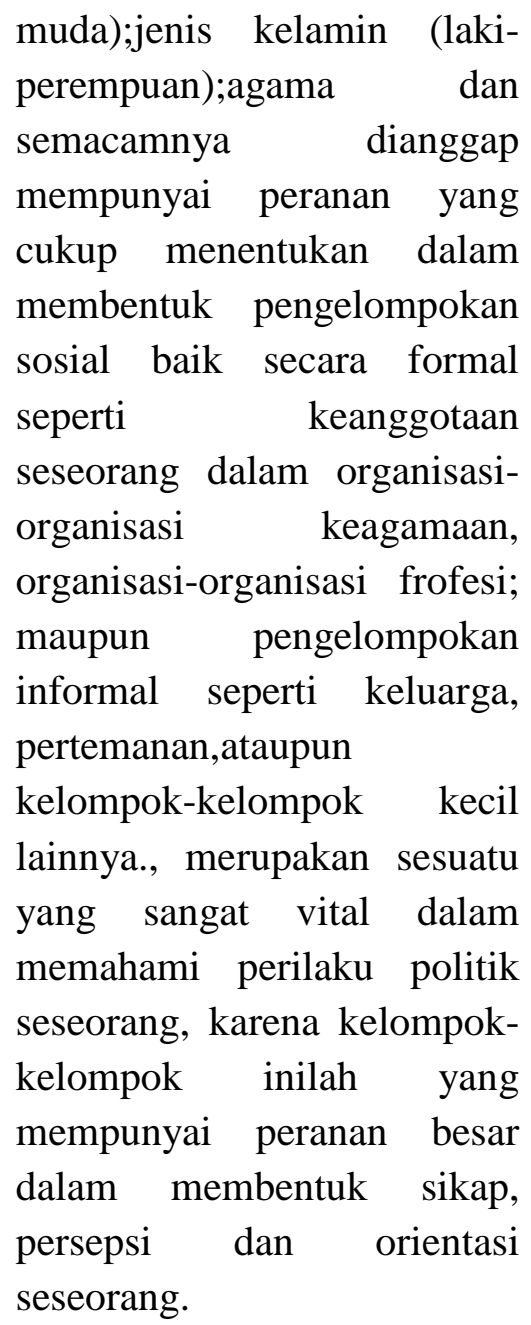

2) Pendekatan Psikologis

Pendekatan sosiologis berkembang di Amerika Serikat berasal dari Eropa Barat, pendekatan Psikologis merupakan fenomena Amerika serikat karena dikembangkan depenuhnya oleh Amerika Serikat melalui Survey Research Centre di Universitas Michigan. Oleh karena itu, pendekatan ini juga disebut sebagai Mazhab Michigan. Pelopor utama pendekatan ini adalah Angust Campbell. Pendekatan ini menggunakan dan mengembangkan konsep psikologi- terutama konsep sosialisasi dan sikap untuk menjelaskan perilaku pemilih. Variabel-variabel itu tidak dapat dihubungkan dengan perilaku memilih kalau ada proses sosialisasi. Oleh karena itu, menurut pendekatan ini sosialisasilah sebenarnya yang menentukan perilaku memilih (politik) seseorang.

Penganut pendekatan ini menjelaskan sikap seseorangsebagai refleksi dari kepribadian seseorangmerupakan variabel yang cukup menentukan dalam mempengaruhi perilaku politik seseorang. Oleh karena itu, pendekatan psikologis menekankan pada tiga aspek psikologis sebagai kajian utama yaitu ikatan emosional pada suatu partai politik, orientasi terhadap isuisu dan orientasi terhadap kandidat.

3) Pendekatan Rasionalitas

Penggunaan pendekatan rasional dalam menjelaskan perilaku pemilih oleh ilmuwan politik sebenarnya diadaptasi dari ilmu ekonomi. Mereka melihat adanya analogi antara pasar (ekonomi) dan perilaku 
memilih (politik). Apabila secara ekonomi masyarakat dapat bertindak secara rasional, yaitu menekan ongkos sekecil-kecilnya untuk memperoleh keuntungan yang sebesarbesarnya, maka dalam perilaku politikpun maka masyarakat akan dapat bertindak secara rasional.

Asumsi pemilih bukan wayang yang tidak memiliki kehendak bebas dari kemauan dalangnya oleh Anthony Downs dalam Economic Theory of Democracy (1957). Artinya, peristiwa-peristiwa politik tertentu dapat mengubah preferensi pilihan seseorang. Dalam pendekatan pilihan rasional ini, dipaparkan dua orientasi yang menjadi daya tarik pemilih, yaitu orientasi isu dan kandidat. Orientasi isu berpusat pada pertanyaan; apa yang seharusnya dan sebaiknya dilakukan untuk memecahkan persoalanpersoalan yang dihadapi masyarakat? Dan orientasi kandidat mengacu pada sikap seseorang terhadap pribadi kandidat tanpa mempedulikan label partainya. Di sinilah para pemilih menentukan pilihannya berdasarkan pertimbangan rasional. Namun terkadang pula para pemilih rasional yang bisa dikatakan sebagai free rider tidak peduli terhadap pemilihan umum, hal ini rasional secara ekonomi. Sebab utamanya adalah usaha yang diperlukan untuk mendapatkan informasi politik tidak sebanding dengan imbalannya

\begin{tabular}{llrr}
\multicolumn{2}{c}{ Berdasarkan } & \multicolumn{2}{r}{ ketiga } \\
pendekatan & tersebut & dan & bila \\
dikaitkan & dengan & fenomena \\
popularitas & selebriti & ke & dalam
\end{tabular}
panggung politik, maka pendekatan psikologi dirasa paling cocok Pemilih memilih dengan berorientasi pada pribadi kandidat tanpa mempedulikan label partainya. Penekanan emosi dan perasaan lebih dikedepankan. Pemilih tetap memilih kandidat dikarenakan rasa "suka" dan bukan karena pertimbangan latar belakang dan program yang diusung kandidat tersebut. Seseorang bisa saja memilih seorang artis hanya karena suka dengan lagunya, goyangannya atau keseksiannya. Atau pun karena popularitas selebriti yang diagung-agungkan oleh media. Seperti pembahasan yang telah dikemukakan sebelumnya bahwa pada dasarnya khalayak dan bintang memiliki hubungan yang khas. Khalayak memandang sang selebriti sebagai gemerlap nun jauh diatas sana. Selebriti tidak dapat tersentuh namun juga menyilaukan. Mimpi dan cita-cita khalayak adalah 
mendekatkan idola yang mereka kultuskan.

Perilaku pemilih dengan pendekatan ini hanya bertahan hanya untuk jangka pendek dan semu. Saat pemilih disadarkan oleh realitas politik bahwa kandidat yang diinginkan tidak mampu menagktualisasikan dirinya, maka perilaku pemilih dapat bergeser dengan meninggalkan kandidat tersebut. Hal ini karena latar pendidikan mereka memang rendah dan konyolnya, partai politik menggunakan kelemahan mereka tersebut. Seharusnya partai politik ikut bertanggung jawab memberikan pendidikan politik kepada simpatisannya, bukan memanfaatkan kebodohan para simpatisannya.

\section{PENUTUP}

Partai politik dewasa ini semakin banyak yang merekrut para artis untuk didudukan sebagai calon anggota Dewan. Rekruitmen para artis yang tiba-tiba diajak menjadi anggota partai politik memang syahsyah saja. Semua berpulang pada kebijakan para pengurus dan pembina partai untuk menentukan kebolehan siapapun menjadi anggota partai politik dan siapa yang akan mewakili parpolnya sebagai caleg, sebanyak 79 calon yang akan duduk di kursi panas Senayan berasal dari kalangan selebriti. Menegaskan bahwa popularitas dapat mendulang suara. Budaya populer yang merasuki ruang public turut menguatkan para selebriti untuk masuk menjadi bagian dalam ajang kompetisi perpolitikkan, budaya pop memberikan ruang lain yang selama ini hanya terisis oleh para elit-elit politik, kaum penguasa, pejabat dan kelompok ningkat. Masyarakat yang terbius atas suguhan instan budaya populer pun tidak segan turut memilih idolanya untuk memberikan kepercayaan untuk memilih mereka sebagai wakil politiknya.

Namun, sebaiknya para selebriti jangan hanya mengunggulkan kecantikan, ketampanan dan juga kepopuleranya saja tetapi juga harus mempunyai kapasitas untuk menjadi seorang politikus, dilatar belakangi pendidikan yang memadai, selain itu juga harus bisa membuktikan kinerja mereka untuk masyarakat. Mereka mampu untuk mengemban suatu amanah dan tanggung jawab, mampu memperjuangkan hak dan nasib rakyat, mensejahterakan rakyat, pengetahuan berpolitknya, dan berpolitik dengan cara yang benar. Karena satu hal yang tidak boleh dikesampingkan begitu saja adalah keinginan dan harapan masyarakat adanya sikap yang lebih bertanggung jawab dari partai politik dalam menempatkan anggotaanggotanya untuk menempati kedudukan sebagai anggota dewan. Partai politik sebaiknya ikut memberikan pendidikan politik kepada masyarakat dengan menyodorkan figur-figur yang dapat 
dipercaya yang dapat memberikan perubahan dan sumbangsih yang lebih baik bagi kehidupan bermasyarakat dan bernegara bukan hanya bermodalkan popularitas sebagai etalase atapun kosmetika politik semata.

\section{Referensi:}

Asfar, M. (2006). Pemilu dan Perilaku Memilih 1995-2004. Surabaya: Pustaka Eureka.

Boorstin, D. J. (1992). The Image : A Guide to Pseudo-events in Amerika. New York: Random House.

Budiardjo, M. (1977). Dasa-dasar Ilmu Politik. Jakarta: PT. Gramedia.

Burke, P. (1978). Popular Culture in Early Modern Europe. London: Temple Smith.

Cohen, B. (1963). The Press and foreign policy. NJ: Princeton University Press.

Fatah, E. S. (2004). Caleg Selebriti Perempuan : Dari Perlengkapan ke Pelaku Politik. Jurnal Perempuan, Jakarta.

Fatwa, A. (2009). Potret Konstitusi Pasca Amandemen 1945.
Jakarta: PT.Kompas Media Nusantara.

Firmanzah. (2007). Marketing Politik. Jakarta.

Guardini, F. (1996). Old and New, Modern and Postmodern : Baroque and Neonaraque. $M c$ Luhan studies.

Liddle, S. M. (12010). Indonesia : personalities parties and voters. Democracy Nolume 21.

LSI. (2001). PEMILIH MENGAMBANG DAN PROSPEK PERUBAHAN KEKUATAN. jakarta.

Mietzner, M. (2009). Political opinion polling in post authoritarian Indonesia Catalyst or obstacle to democratic consolidation. Bijdragen tot de Taal-, Landen.

Strinati, D. (2003). Popular Culture : Pengantar Menuju Teori Budaya Populer. Yogyakarta: Bentang.

Sufyanto. (2015). Selebritisasi Politik. Bandung: Nusa Media.

Surbakti, R. (1997). Partai, Pemilih dan Demokrasi. Yogyakarta: Pustaka Pelajar. 